Paperback edition

Red, Black, and Green

Black Nationalism in the United States

\title{
ALPHONSO PINKNEY
}

An analysis of the history of black nationalism in the United States which concentrates on the ascendancy of the phenomenon during the peak years of the 1960s and early 1970s.

"This is one of the best of a number of publications on black nationalism. ... . It is scholarly, yet is written in a language that

can easily be understood, and appreciated by the lay public.' Sociology

Paperback $\mathbf{2 3 . 9 5}$ net

\section{Crisis and Legitimacy}

The Administrative Process and American Government

\section{JAMIES O. FREEDMAN}

$\therefore$... very original in thought and very impressive in presentation.

It is, no doubt, an important contribution to the study of

administrative law.' -Itzhak Zamir, Attorney General of Israel

$\because \ldots$ an admirable study of administrative action, a study conducted

at every level. .... Andre Tunc in the International Review of

Comparative Law

$£ 11.50$ net

\section{The Economic Rise of Early America}

\section{GARY M. WALTON and JAMES F. SHEPHERD}

The authors analyse the development of the colonial economy from the early settlement days to the period of the Revolutionary War. They examine the economy in terms of significant commodities and their regional and international markets, and then evaluate the effects of commercial developments in these areas upon urbanisation as well as shipping and trade.

Hard covers £11.50 net Paperback 23.95 net

\section{One Kind of Freedom}

The Economic Consequences of Emancipation

\section{ROGER RANSOM and RICHARD SUTCH}

The authors contend that the kind of freedom permitted to negroes in the post-emancipation southern states of America produced substantial increases in their economic welfare, but at the same time curtailed further black advancement and retarded economic development in the late nineteenth century.

\section{CAMBRIDGE UNIVERSITY PRESS}




\title{
THE EAGLE ENTANGLED U.S. Foreign policy in a Complex World Oye, Rothchild and Lieber
}

Over the past decade, the task of developing a coherent and effective American foreign policy has become increasingly difficult. This volume discusses the consequences of these changes. Why have American policy options narrowed? How well has the Carter administration coped with these changes? Are these trends likely to persist, and need they confound policy makers in the 1980's? In addressing these questions the authors move from chapters on the domestic and international setting of foreign policy to ten critical issues including the Soviet Union, Eurocommunism the Arab-Israeli dispute and nuclear expansion.

Available August

Paper 582290023

363 pages

£6.95 net

\section{Longman}

\section{The Rockefeller Foundation announces}

\section{TWO INTERNATIONAL PROGRAMS}

\author{
at the
}

\section{BELLAGIO STUDY AND CONFERENCE CENTER}

\section{Bellagio (Como), Italy}

International Conferences-small conferences or working groups focusing on topics or problems of international significance.

Scholars in Residence-an opportunity for scholars to work for approximately four weeks on individual projects.

The Foundation provides the facilities of the Center, located about 40 miles north of Milan, on a competitive basis to residents and conference organizers. It normally does not pay for related costs, such as transportation, of the participants in these two programs.

For more information, write:

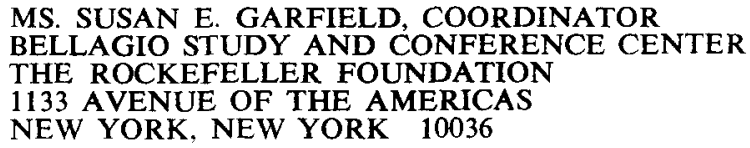




\section{Oxford University Press}

\section{The Populist Movement}

\section{A Short History of the Agrarian Revolt in America Lawrence Goodwyn}

This is an abridged edition of Professor Goodwyn's Democratic Promise $(£ 12,1978)$, which has been recognized as the basic study of the Populist Movement in America. 'This book is about the decline of freedom in America,' says the author, and he proceeds to overturn three generations of historical literature on Populism and to cast a radically new light on what he calls the undemocratic 'progressive society' of twentieth-century America. Paper covers $£ 2.95$ Galaxy Books

\section{Slave Religion}

\section{The 'Invisible Institution' in the Antebellum South Albert J. Raboteau}

This book studies the Black religious experience under slavery from its African roots through its reinterpretation and reconstitution under Christianity. The author examines the influence of African religious perspectives on the ideology of Christianity and the special way in which Black slaves converted the expression of religiosity into one of the most creative experiences of the Black in servitude. Illustrated $£ 7.95$

\section{A Feast of Words}

\section{The Triumph of Edith Wharton Cynthia Griffin Wolff}

A product of the most aristocratic element of New York society in the late nineteenth century, a society that positively discouraged women from any occupation save motherhood and becoming a good hostess. Edith Wharton seemed the most unlikely sort of person to be a writer. Yet she became a great novelist. How and why she did so is explained in this full-scale examination of Edith Wharton's works and of her unpublished autobiographical recollections and fiction. This is a paperback edition of the book first published in 1977 and still available in cloth at $£ 8.25$. Illustrated paper covers $£ 3.50$ Galaxy Books

\section{Representative Man}

Ralph Waldo Emerson in his Time Joel Porte

This is a new biographical study of one of the great American writers. The book is divided into the four seasons of Emerson's life: 'Rites of Spring'; 'A Summer of Discontent: Emerson in 1838'; 'The Fall of Man'; and 'A Winter's Tale: The Elder Emerson'. Each part starts with a brief biographical and chronological sketch, then discusses the events and works which together convey the best intellectual portrait of Emerson at that period of his life. Illustrated $£ 8.50$ 


\section{Oxford University Press}

\section{Seven Days a Week}

\section{Women and Domestic Service in Industrializing America David M. Katzman}

The industrialization of America brought about massive changes in most sectors of American life. In at least one sector, however-the household-the effects were minimized by the presence and persistence of domestic servants. In this investigation of domestic service in America between the Civil War and the First World War, the author presents a vivid picture of the limitations and hardships faced by the servants, describes servant-employer relations, and shows how the kind of people in service changed as new occupations in shop, factory, and office opened up to women. $\mathbf{f 7 . 7 5}$

\section{Democracy and the Novel}

\section{Popular Resistance to Classic American Writers Henry Nash Smith}

This book discusses problems arising from the relation between certain major American novelists of the nineteenth century and American popular culture of the period. While the writers of the time had to make some contact with the new mass audience if their work was to survive, they actively resisted it. Among the novelists discussed in this reinterpretation of nineteenth-century American literature are Hawthorne and Melville, William Dean Howells, Mark Twain, and Henry James. $\quad \mathbf{1 7 \cdot 2 5}$

\section{A Companion to California James D. Hart}

The author of the Oxford Companion to American Literature has followed the model of that book, and of other Oxford Companions, in compiling this reference book to the State of California: its climate, people, architecture, literature, education, flora, fauna, etc. There are over a thousand entries on topics ranging from hotels, banks, newspapers, and missions, to figures from the world of politics, films, and popular music. $£ 10$

\section{The Last Romantic}

\section{The Life of Max Eastman}

\section{William L. O'Neill}

Max Eastman's great creation was his own life. A key figure on the American cultural scene for over half a century, Eastman was a prominent member of the Bohemian set in Greenwich Village, was put on trial for his anti-war opinions, edited The Liberator, a radical magazine, after World War I, was one of the first American intellectuals to live in Soviet Russia, later turned against Stalinism and wrote significant books criticizing Russian communism, and then threw away his new-found respectability by joining the Readers' Digest. Illustrated $£ 8 \cdot 50$ 


\section{THE POLITICS OF POWER}

\section{A Critical Introduction to American Government}

\section{Ira Katznelson}

\section{and Mark Kesselman}

This Second Edition of The Politics of Power continues to provide a critical analysis of contemporary American political institutionsone that emphasizes the structure of society and the power relationships between corporate capitalism and the government. It reflects the authors' point of view that the organizational structure of corporate production and the intimate relationship between government and corporate capitalism are directly responsible for the persistent inequalities in American society.

\section{WHY THEY CALL IT POLITICS}

$3 r d$ edition

\section{A Guide to America's Government}

\section{Robert Sherrill}

A witty, provocative and immensely readable survey of the American political system by one of America's best-known political journalists. Sherrill's knowledgeable approach to our political institutions is irresistible to readers of all persuasions. For this edition the author has rewritten every chapter, paying particular attention to the Presidency, energy and resources and the economy, and has added a new chapter on domestic policy.

\section{DEMOCRACY UNDER PRESSURE $3 r d$ edition} An Introduction to the American Political System

\section{Milton C. Cummings} and David Wise

The Third Edition of this extraordinarily successful introduction to American government maintains the aims, techniques, and outstanding features so widely praised in earlier editions: it combines a critical yet balanced examination of the structure and processes of the American political system-one that focuses not only on the very considerable achievements of the system but on its shortcomings as well-with a contemporary viewpoint and a clear, highly readable style. The authors, one a distinguished political scientist, the other a leading political writer, present American government and political institutions in historical context but consistently relate them to contemporary issues. The result is a textbook that is stimulating, exciting, authoritative, and comprehensive. 


\section{The Winner}

of the 1979

Frederick Jackson Turner

Award

\section{FINLEY PETER DUNNE}

\& MR. DOOLEY

The Chicago Years

Charles Fanning

“Highly recommended to anyone interested in

American history

and literature"-Choice.

296 pages

Illustrations

$\$ 14.50$

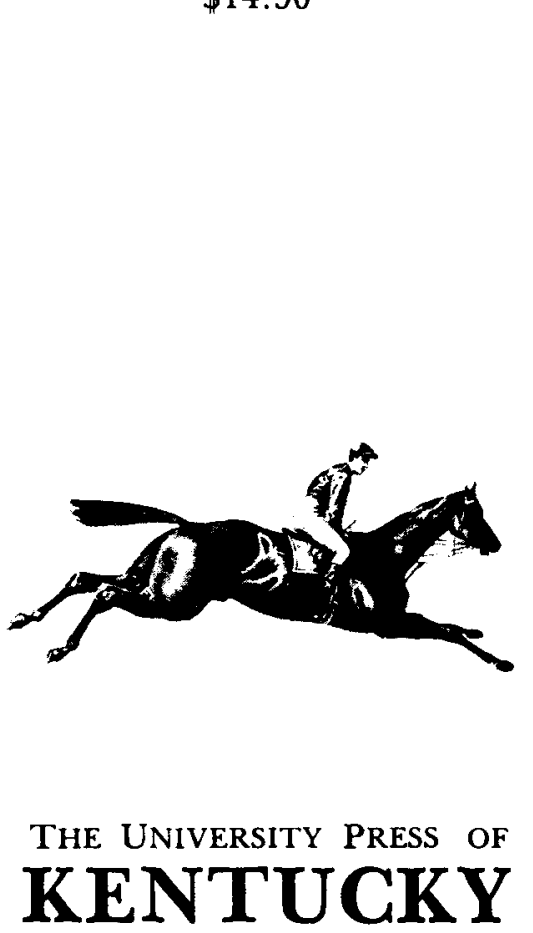

LEXINGTON 40506 
I All contributions and editorial correspondence should be sent to: The Editor, Journal of American Studies, School of English and American Studies, University of East Anglia, Norwich NR4 7 TJ, England.

2 Articles should generally contain about 5,000 words. Longer or shorter articles, or articles in two or more parts, may be accepted by arrangement with the Editors.

3 Submission of an article is taken to imply that it has not previously been published, and is not being considered for publication elsewhere.

4 Contributions should be clearly typed in double spacing (including footnotes), preferably on $\mathrm{A}_{4}$ paper, with a wide left-hand margin. Diagrams, maps and illustrations may be included.

5 Spelling may conform either to British or American usage, providing it is consistent throughout.

6 Footnotes should be used sparingly : in general, to give sources of direct quotations, references to main authorities on disputable questions, and evidence relied on for a new or unusual conclusion. They should be numbered consecutively, and may most conveniently be placed, in double spacing, at the end of the article.

7 For guidance on matters of style, contributors should refer either to the MLA Style Sheet (2nd ed.), or to the Journal of American Studies Style Notes, copies of which may be obtained from the Editors.

8 Contributors should keep one copy of the typescript for correcting proofs.

9 Notes intended for the Editors or printer should be on a separate sheet.

Io First proofs may be read and corrected by contributors provided that they can give the Editor an address through which they can be reached without delay and can guarantee to return the corrected proofs to the Editor, by airmail where necessary, within three days of receiving them.

II Corrections should be kept to an absolute mirtimum. They should be confined to errors of the typist or printer unless the Editor authorizes otherwise.

I2 Contributors of articles and review essays receive 25 free offprints. Extra copies may be ordered according to a scale of charges.

I3 Contributors need not be members of the British Association for American Studies. Unsolicited typescripts can only be returned to overseas contributors who send International Reply Coupons (not postage stamps).

14 Contributors of accepted articles will be asked to assign their copyrights, on certain conditions, to Cambridge University Press, to help protect their material, particularly in the USA. 


\section{Journal of American Studies}

Kennedy, Congress and Civil Rights

Climate, Health and Black Labor in the English Americas

GARY PUCKREIN

Slave Trading in the Ante-Bellum South: An Estimate of the Extent of the Inter-Regional Slave Trade

MICHAEL TADMAN

Proletarian Literature and the John Reed Clubs 1929-1935

ERIC HOMBERGER

Theories of American Labour Violence

RHODRI JEFFREYS-JONES

\section{Review Essay}

Women as Poets

DIANA COLLECOTT SURMAN

Reviews

(C) Cambridge University Press 1979

\section{Cambridge University Press}

The Pitt Building, Trumpington Street, Cambridge $\mathrm{CB}_{2}$ IRP 32 East $57_{\text {th }}$ Street, New York, NY 10022 